\title{
Habitat related variations in omega series of unsaturated fatty acids in Indian major Carp Cirrhinus mrigala
}

\author{
Bilal Hussain ${ }^{1,2}$, Tayyaba Sultana ${ }^{1}$, Salma Sultana ${ }^{1}$, Farhat Jabeen ${ }^{1}$, \\ Shahid Nadeem ${ }^{3}$ and Shahid Mahboob ${ }^{1}$ \\ 1-Department of Zoology, Wildlife and Fisheries, Govt. College University, Faisalabad, Pakistan. \\ 2-Department of Bioinformatics and Biotechnology, Govt. College University, Faisalabad, Pakistan. \\ 3-Nuclear Institute for Agriculture and Biology, Faisalabad, Pakistan. \\ Corresponding author email: profbilal@yahoo.com \\ Citation \\ Bilal Hussain, Tayyaba Sultana, Salma Sultana, Farhat Jabeen, Shahid Nadeem and Shahid Mahboob. Habitat \\ related variations in omega series of unsaturated fatty acids in Indian major Carp Cirrhinus mrigala. Pure and \\ Applied Biology. Vol. 3, Issue 4, 2014, pp 192-198
}

\begin{abstract}
Atomic absorption spectrophotometery showed significant levels of contamination by $\mathrm{Cd}, \mathrm{Hg}, \mathrm{Cu}, \mathrm{Mn}, \mathrm{Zn}, \mathrm{Pb}, \mathrm{Cr}$ and $\mathrm{Sn}$ in fish habitats. Fatty acids from meat were detected by gas chromatography. C12:0, C20:0, C16:1(n-7), C16:1(n-9), C18:1(n-9), C20:1(n-9), C18:2(n-6), C18:4(n-3), C22:4(n-6), C20:5(n-3) and C22:4(n-6) fatty acids were found missing in fish obtained from area of higher pollution when compared to farmed fish.C16:1(n-7), C20:1(n-9), C20:2(n-6), C22:4(n-6) and C22:5(n-3) were found missing in the fish collected upstream to the areas of high intensity pollution. Loss of these important fatty acids indicates the sensitivity of the fish even in response to the lower intensity of pollution. Farmed fish showed optimal concentration of each fatty acid. Significant differences $(\mathrm{p}<0.05)$ were observed in fatty acid profiles of different species when each was compared in relation to their own habitats. Habitat of even lower intensity pollution confiscates fatty acids of omega series and lower down the unsaturated fats for which fish is preferred on other animals.
\end{abstract}

Key words: Pollution load, fish, devastation, fatty acid profile.

Introduction

Fish culture is considered today as one of the most promising sources of animal proteins. During recent past, potential and prolific nature of fish culture has been directed towards its large scale adoption and promotion in Asian countries. Traditionally Indian major carps, viz. Catla catla, Labeo rohita and Cirrhinus mrigala are commonly cultured in freshwater ponds. Fish are not only protein source but also contain considerable amount of unsaturated fatty acids. In recent years, fish lipids have also assumed a great nutritional significance owing to their protective role against the development of cardiovascular diseases and rheumatoid arthritis [13]. Coronary heart diseases have been identified as a leading cause of death in various parts of the world including Pakistan, with mortality rates increasing every year.

Fish lipids are rich in polyunsaturated fatty acids (PUFA), which are essential for fish health and growth. In comparison with terrestrial animal meat, fish lipids are beneficial to human health by reducing the risk of cardiovascular and inflammatory disorders $[2,4,5]$. Fishes store lipids in muscles and liver in contrary to majority of mammals which store lipids in adipose tissues [6,7]. With increasing demand, population of the fish species in different areas of the world has decreased drastically due to pollution and over fishing. Polluted water from industrial and urban areas of Faisalabad is disposed into the River Chenab which has led to the extinction and decrease in population of different species of the fishes in almost $190 \mathrm{Km}$ length of the River Chenab. The present project is planned to evaluate the effect of pollution on the fatty acid profile of the fish in order to make it unambiguous that fish not only bioaccumulate toxicants in their body but also endow with reduced quality of the meat. There is awful need to reduce environmental pollution so that next generation may enjoy well quality fish meat with high quality lipid profile.

Materials and methods

Bottom feeder Cirrhinus mrigala (Indian major carps) collected from highly polluted areas, less 
polluted areas and farmed fish were analyzed for the estimation of fatty acids profile.

\section{Procurement of Fish}

Fish species were harvested from the River Chenab through its $190 \mathrm{~km}$ of length in the District Jhang from Thatta Muhammad Shahh to Trimu Head. This is an area of high pollution because sewage and industrial wastes are disposed into the River Chenab through Chakbandi Drain at this point at latitude $31.570^{\circ}$ and longitude $72.534^{\circ}$. Except rainy season only this polluted water flows through the River Chenab up to Trimu Head. Drag nets and gill nets were used to harvest fish from these highly polluted areas of the River. For control fish were harvested upstream from Tatta Muhammmad Shah at the point Thalli comparatively less polluted areas of the River Chenab. To make the results more explicate these fishes were compared to farmed fish devoid of any type of pollution.

\section{Preparation of Fish for Experiment}

All the fish specimens were freshened out in running de-chlorinated tap water, thereby, facilitating the emptying and removal of stomach contents. Fish were then, slaughtered and dressed, which consisted of removing visceral organs, followed by meat filleting. Wild and farmed fish species were analyzed fresh each time for fatty acid profile.

\section{Water Analysis}

Water samples of the River Chenab were taken from areas of fish harvest and analyzed for selected heavy metals and other water quality parameters defined by Environmental protection Agency of Pakistan. Seven Surface, column and bottom water samples of about 1.5 liter (each) were collected in polypropylene bottles from each site and preserved in $5 \mathrm{ml}$ of $55 \%$ $\mathrm{HNO}_{3} / \mathrm{L}$ of water to prevent metal adsorption on the inner surface of the container and stored at $4{ }^{\circ} \mathrm{C}$ before their analyses defined by Boyed (1981) [8]. Metals analyzed were tin ( $\mathrm{Sb}$ ), chromium $(\mathrm{Cr})$, lead $(\mathrm{Pb})$, Zinc $(\mathrm{Zn})$, manganese $(\mathrm{Mn})$, cupper $(\mathrm{Cu})$, cadmium $(\mathrm{Cd})$, and mercury $(\mathrm{Hg})$. Concentration of each metal was detected by using heavy metal kits (Merck Germany) and by using Hitachi polarized Zeeman Atomic Absorption Spectrophotometer AAS, 2000 series.

\section{Fatty Acid analysis}

Lipids were extracted according to Folch et al. [9], as modified by Bell et al. [10] by further improvement of unit by execution of Soxlet unit into Licon Nicolson concurrent distillation unit for rapid extraction. Seven fish specimen were used and fresh fish flesh tissues from each fish in replica of seven were oven dried and ground to made powder. Total lipids (oils and fats) were extracted by using soxhlet apparatus by $\mathrm{n}$-Hexane heated at $65^{\circ} \mathrm{C}$. Extracted lipids were converted to fatty acid (FA) methyl esters by methanolic sulfuric acid through esterification process and after treating with ether samples were injected into the Gas Chromatograph. Chromatograms produced by each sample gave the retention time of each fatty acid (Fatty acid methyl esters (FAMEs)) were compared to the chromatogram of standard (mixture of pure FAMEs). Fatty acids were determined by gas-liquid chromatography, by using Flame Ionization detector according procedure defined by Kiessling et al.[6].

\section{Statistical analysis}

Different Procedure of Statistical Analysis System ANOVA by Minitab packages [11] was used to analyze the data. Results are presented as means and standard errors (SE) of physicochemical parameters and fatty acids in each category. Means of fatty acid profiles were segregated according to the RyanEinot-Gabriel-Welch Multiple Range Test (REGWq). Data subjected to other tests by using SPSS program version 10.0 to perform the analysis.

\section{Results and discussion}

Water analysis clearly showed significant change in the water quality of the River Chenab after receiving this drain. All water quality parameters were found far above than WHO permissible limits (Fig. 1; Table-1). The data shown for individual fatty acid of total lipids are limited to, fish flesh of two category habitats. One from highly polluted areas, where industrial and domestic wasters are disposed into the River Chenab through chakbandi drain and other from comparatively less polluted areas of the River Chenab upstream before the disposal of this drain to river. These two categories were compared to farmed fish. Comparison of above mentioned two categories provided clear evidence for domino effects that this environment has developed into very toxic habitat not suitable for the growth of fish to produce high quality meat. Higher concentrations of heavy metals in the water not only bioaccumulate in the fish body but also get in the way of metabolism hence reducing the quality of the fish [12].

Fish from highly polluted locale showed less number of fatty acids identified and more saturated fatty acids in their meat (Fig. 2) as compared to fish from less polluted areas. Here it is important to point out that Cirrhinus mrigala showed non-significant differences in the amount of saturated and unsaturated fatty acids from both wild categories indicating its higher sensitivity for pollution. This is due to the fact that pollution sediment with the passage of time [13] in the bottom and Cirrhinus mrigala is bottom feeder fish having maximum exposure to the pollution.

C12:0, C20:0, C16:1(n-7), C16:1(n-9), C18:1(n-9), C20:1(n-9), C18:2(n-6), C18:4(n-3), C22:4(n-6), C20:5(n-3), C22:4(n-6) and C22:5(n-3) fatty acids 




Fig. 1. Comparison of heavy metals in fish environments. HPH: highly polluted habitat, LPH: less polluted habitat. Control: farmed.

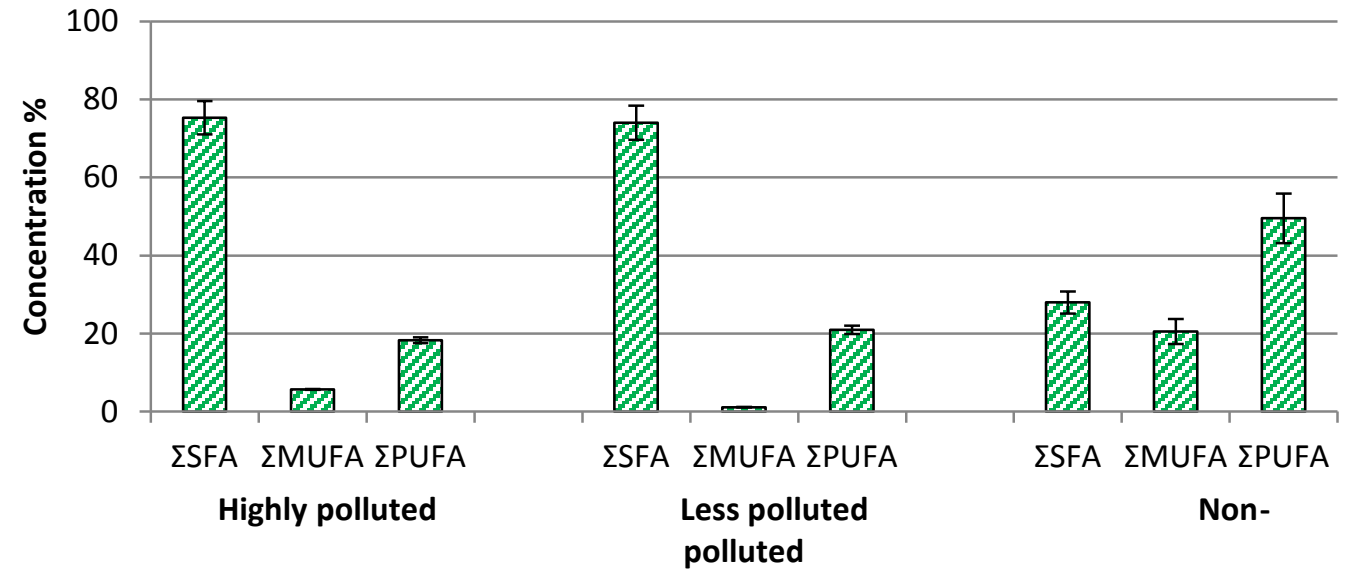

Fig. 2. Total lipids and fatty acid profile of Cirrhinus mrigala from three different habitats. $\Sigma$ SFA; saturated fatty acids, $\Sigma$ MUFA; monounsaturated fatty acids, $\Sigma$ MUFA; polyunsaturated fatty acids.

Table 1. Change in the water quality of the River Chenab due to pollution load.

\begin{tabular}{|c|c|c|c|}
\hline Water Quality Parameters & Highly Polluted water & $\begin{array}{c}\text { Less Polluted water } \\
\text { (Upstream) }\end{array}$ & Control (Farmed) \\
\hline $\mathrm{pH}$ & $11.6 \pm 0.23$ & $8.0 \pm 0.01$ & $7.9 \pm 0.00$ \\
\hline BOD & $76.70 \pm 0.03$ & $44.9 \pm 0.03$ & $33.50 \pm 0.13$ \\
\hline COD & $192.0 \pm 0.05$ & $67.2 \pm 0.05$ & $60.0 \pm 0.05$ \\
\hline TDS & $2399 \pm 1.47$ & $1295 \pm 0.99$ & $319 \pm 0.47$ \\
\hline TSS & $301 \pm 0.09$ & $207 \pm 0.22$ & $179 \pm 0.82$ \\
\hline Salinity & $1900 \pm 0.07$ & $401 \pm 0.21$ & $200 \pm .032$ \\
\hline Conductivity & $3.214 \pm 0.01$ & $1.32 \pm 0.03$ & $0.29 \pm 0.01$ \\
\hline Phenols & $2.22 \pm 0.01$ & $0.72 \pm 0.01$ & $0.14 \pm 0.00$ \\
\hline Sulphates & $431 \pm 0.06$ & $318 \pm 0.23$ & $79 \pm 0.55$ \\
\hline
\end{tabular}

Values $\mathrm{mg} / \mathrm{L}$ (Mean \pm SE) are average of five samples analyzed in triplicate. BOD: Biological oxygen demand, COD: Chemical oxygen demand. TDS: Total Dissolved solids, TSS: Total suspended solids 
Table 2. Fatty acid profile $\%$ (Mean \pm S.E) of Cirrhinus mrigala meat collected from three different habitats in pollution spectra.

\begin{tabular}{|c|c|c|c|}
\hline Fatty acids & Highly Polluted habitat & Less polluted area (Upstream) & Non-polluted (Farmed) \\
\hline \multicolumn{4}{|c|}{ Saturated fatty acids } \\
\hline C10:0 & $07.7949 \pm 0.88 \mathrm{~b}$ & $01.3262 \pm 0.04 \mathrm{ad}$ & $03.4125 \pm 0.05 \mathrm{ac}-\mathrm{f}$ \\
\hline C12:0 & ------ & $00.6923 \pm 0.05$ abe & $01.0547 \pm 0.03 a b c$ \\
\hline $\mathrm{C} 14: 0$ & $02.4699 \pm 0.05 \mathrm{abd}$ & $00.4762 \pm 0.01 \mathrm{~b}$ & $04.2143 \pm 0.09$ be \\
\hline C16:0 & $54.9414 \pm 2.14 \mathrm{def}$ & $41.9244 \pm 1.09 \mathrm{ab}$ & $12.0025 \pm 0.23$ abe \\
\hline C18:0 & $10.1358 \pm 0.15 \mathrm{gh}$ & $28.4393 \pm 2.04 \mathrm{cde}$ & $07.0658 \pm 0.10 \mathrm{ab}$ \\
\hline $\mathrm{C} 20: 0$ & -------- & $01.1707 \pm 0.02 \mathrm{ah}$ & $00.2540 \pm 0.10 \mathrm{abd}$ \\
\hline$\Sigma$ SFA & $75.3370 \pm 0.80$ abef & $74.0291 \pm 0.54 \mathrm{ab}$ & $28.0038 \pm 0.07 \mathrm{ab}$ \\
\hline \multicolumn{4}{|c|}{ Monounsaturated fatty acids } \\
\hline C16:1(n-7) & - n & - & $00.5073 \pm 0.02 \mathrm{~b}$ \\
\hline C16:1(n-9) & ------- & $00.3900 \pm 0.01 \mathrm{abh}$ & $02.5471 \pm 0.01$ ace \\
\hline $\mathrm{C} 18: 1(\mathrm{n}-7)$ & $00.4688 \pm 0.08$ af & $00.3472 \pm 0.03$ bef & $01.4587 \pm 0.02$ ace \\
\hline C18:1(n-9) & --- & $00.0742 \pm 0.12 \mathrm{ab}$ & $11.8905 \pm 0.07 \mathrm{abd}$ \\
\hline C20:1(n-9) & --- & --------- & $03.5412 \pm 0.19 \mathrm{ad}$ \\
\hline$C 22: 1(n-9)$ & $05.2212 \pm 0.10 \mathrm{bc}$ & $00.3526 \pm 0.10 \mathrm{ab}$ & $00.6039 \pm 0.03 \mathrm{ad}$ \\
\hline ¿MUFA & $05.6900 \pm 0.09 \mathrm{c}-\mathrm{f}$ & $01.1640 \pm 0.06 \mathrm{abc}$ & $20.5481 \pm 0.05 \mathrm{abf}$ \\
\hline \multicolumn{4}{|c|}{ Polyunsaturated fatty acids } \\
\hline C18:2(n-6) & (----- & $01.1625 \pm 0.09$ abe & $00.0122 \pm 0.02$ abe \\
\hline $\mathrm{C} 18: 3(\mathrm{n}-3)$ & $02.4446 \pm 0.12 b c$ & $04.0059 \pm 0.02 \mathrm{abf}$ & $06.2521 \pm 0.12$ abe \\
\hline $\mathrm{C} 18: 4(\mathrm{n}-3)$ & ------- & $00.3921 \pm 0.07$ ade & $00.5543 \pm 0.01$ ace \\
\hline $\mathrm{C} 20: 2(\mathrm{n}-6)$ & $00.9421 \pm 0.09 \mathrm{bdf}$ & ------------ & $00.6302 \pm 0.01 \mathrm{ab}$ \\
\hline $\mathrm{C} 20: 4(\mathrm{n}-6)$ & $08.2893 \pm 0.03$ adef & $00.4425 \pm 0.04$ abe & $10.6500 \pm 0.62 \mathrm{abc}$ \\
\hline$C 20: 5(n-6)$ & $03.0386 \pm 0.10 \mathrm{ah}$ & $07.6222 \pm 0.09$ afe & $00.1140 \pm 0.12 b c$ \\
\hline $\mathrm{C} 20: 5(\mathrm{n}-3)$ & ---- & $00.1199 \pm 0.13$ abe & $07.8503 \pm 0.42$ bce \\
\hline $\mathrm{C} 22: 4(\mathrm{n}-6)$ & --- & ---------- & $00.4441 \pm 0.01 \mathrm{abc}$ \\
\hline$C 22: 5(n-6)$ & $00.1366 \pm 0.03 \mathrm{abg}$ & $04.9590 \pm 0.06$ ace & $06.0210 \pm 0.06 \mathrm{ab}$ \\
\hline $\mathrm{C} 22: 5(\mathrm{n}-3)$ & $03.3439 \pm 0.04 \mathrm{acd}$ & ---------- & $02.0129 \pm 0.02 \mathrm{ab}$ \\
\hline $\mathrm{C} 22: 6(\mathrm{n}-3)$ & $00.1151 \pm 0.02 \mathrm{abc}$ & $02.2750 \pm 0.03$ ade & $07.0014 \pm 0.14 \mathrm{abd}$ \\
\hline$\Sigma$ PUFA & $18.3102 \pm 0.06 \mathrm{ab}$ & $20.9791 \pm 0.07$ abe & $49.5425 \pm 0.14 \mathrm{ab}$ \\
\hline
\end{tabular}

SFA; Saturated fatty acids, MUFA; Monounsaturated fatty acids, PUFA; Polyunsaturated fatty acids. Means sharing similar letter in a row or in a column are statistically non-significant $(\mathrm{P}>0.05)$. 
Table 3.Correlation coefficient matrix for unsaturated fatty acids and WQPs along with selected heavy metals.

\begin{tabular}{|c|c|c|c|c|c|c|c|c|c|c|c|}
\hline Fatty Acids & BOD & COD & Phen & Cd & $\mathrm{Cu}$ & Mn & $\mathbf{Z n}$ & $\mathbf{P b}$ & $\mathrm{Cr}$ & Sn & $\mathbf{H g}$ \\
\hline \multirow[t]{2}{*}{ C16:1(n-7) } & -0.548 & 0.562 & 0.866 & 0.701 & 1.000 & -0.021 & 0.405 & 0.452 & 0.761 & 0.439 & 0.627 \\
\hline & 0.631 & 0.036 & 0.000 & 0.000 & 0.016 & 0.944 & 0.068 & 0.040 & 0.000 & 0.047 & 0.002 \\
\hline \multirow[t]{2}{*}{ C16:1(n-9) } & 0.999 & 0.808 & 0.893 & 0.743 & 0.039 & -0.072 & 0.665 & 0.062 & 0.734 & 0.699 & 0.638 \\
\hline & 0.027 & 0.000 & 0.000 & 0.000 & 0.894 & 0.681 & 0.001 & 0.791 & 0.000 & 0.000 & 0.002 \\
\hline \multirow[t]{2}{*}{ C18:1(n-7) } & -0.138 & 0.555 & 0.541 & 0.972 & -0.113 & 0.883 & 0.754 & 0.812 & 0.947 & 0.671 & 0.445 \\
\hline & 0.912 & 0.040 & 0.011 & 0.151 & 0.701 & 0.000 & 0.000 & 0.094 & 0.000 & 0.001 & 0.043 \\
\hline \multirow[t]{2}{*}{ C18:1(n-9) } & 0.018 & 0.701 & 0.942 & 0.765 & 0.766 & 0.948 & 0.724 & 0.685 & 0.545 & -0.724 & 0.774 \\
\hline & 0.988 & 0.005 & 0.000 & 0.000 & 0.000 & 0.000 & 0.000 & 0.035 & 0.000 & 0.000 & 0.000 \\
\hline \multirow[t]{2}{*}{ C20:1(n-9) } & 0.087 & 0.040 & 0.865 & -0.007 & 0.312 & 0.642 & -0.387 & 0.667 & 0.962 & 0.878 & 0.664 \\
\hline & 0.945 & 0.891 & 0.000 & 0.980 & 0.278 & 0.000 & 0.172 & 0.001 & 0.000 & 0.000 & 0.001 \\
\hline \multirow[t]{2}{*}{ C22:1(n-9) } & 0.984 & 0.522 & 0.711 & 0.542 & -0.091 & 0.561 & 0.405 & 0.248 & 0.553 & 0.507 & 0.611 \\
\hline & 0.114 & 0.056 & 0.000 & 0.011 & 0.758 & 0.008 & 0.068 & 0.279 & 0.009 & 0.019 & 0.003 \\
\hline \multirow[t]{2}{*}{ C18:2(n-6) } & 0.989 & 0.522 & 0.879 & 0.932 & 0.002 & 0.891 & 0.496 & 0.699 & 0.212 & 0.959 & 0.505 \\
\hline & 0.096 & 0.056 & 0.000 & 0.236 & 0.993 & 0.000 & 0.000 & 0.000 & 0.357 & 0.000 & 0.020 \\
\hline \multirow[t]{2}{*}{ C18:3(n-3) } & 0.989 & 0.345 & 0.248 & 0.553 & 0.653 & 0.576 & -0.741 & 0.494 & 0.640 & 0.921 & 0.333 \\
\hline & 0.096 & 0.227 & 0.394 & 0.009 & 0.001 & 0.006 & 0.000 & 0.023 & 0.002 & 0.000 & 0.140 \\
\hline \multirow[t]{2}{*}{ C18:4(n-3) } & 0.906 & 0.814 & 0.182 & 0.770 & 0.487 & 0.970 & 0.976 & 0.563 & 0.946 & 0.966 & 0.575 \\
\hline & 0.279 & 0.000 & 0.534 & 0.000 & 0.025 & 0.158 & 0.139 & 0.008 & 0.000 & 0.000 & 0.006 \\
\hline \multirow[t]{2}{*}{$C 20: 2(n-6)$} & -0.689 & 0.211 & -0.224 & 0.159 & 0.554 & 0.863 & 0.882 & 0.494 & 0.545 & 0.519 & 0.576 \\
\hline & 0.006 & 0.469 & 0.440 & 0.586 & 0.000 & 0.000 & 0.000 & 0.023 & 0.011 & 0.000 & 0.006 \\
\hline \multirow[t]{2}{*}{$C 20: 4(n-6)$} & 0.986 & 0.609 & 0.575 & 0.558 & 0.576 & 0.487 & 0.411 & 0.329 & 0.574 & 0.509 & 0.320 \\
\hline & 0.107 & 0.003 & 0.006 & 0.009 & 0.006 & 0.025 & 0.064 & 0.145 & 0.007 & 0.018 & 0.157 \\
\hline \multirow[t]{2}{*}{$\mathrm{C} 20: 5(\mathrm{n}-6)$} & 0.976 & 0.782 & 0.277 & 0.334 & 0.775 & 0.450 & 0.786 & -0.042 & -0.295 & 0.161 & 0.817 \\
\hline & 0.141 & 0.000 & 0.337 & 0.243 & 0.000 & 0.041 & 0.000 & 0.856 & 0.127 & 0.414 & 0.000 \\
\hline \multirow[t]{2}{*}{$\mathrm{C} 20: 5(\mathrm{n}-3)$} & 0.002 & 0.793 & -0.821 & -0.375 & 0.558 & 0.086 & 0.228 & 0.112 & 0.560 & 0.769 & 0.253 \\
\hline & 0.588 & 0.000 & 0.000 & 0.027 & 0.009 & 0.710 & 0.321 & 0.630 & 0.008 & 0.000 & 0.193 \\
\hline \multirow[t]{2}{*}{$C 22: 4(n-6)$} & -0.490 & 0.609 & -0.071 & 0.086 & 0.154 & 0.544 & -0.002 & 0.066 & 0.978 & 0.958 & 0.368 \\
\hline & 0.674 & 0.003 & 0.955 & 0.945 & 0.902 & 0.011 & 0.994 & 0.778 & 0.000 & 0.184 & 0.101 \\
\hline \multirow[t]{2}{*}{$C 22: 5(n-6)$} & 0.786 & 0.575 & 0.224 & 0.078 & 0.561 & 0.800 & 0.750 & 0.257 & 0.690 & 0.447 & 0.624 \\
\hline & 0.000 & 0.006 & 0.329 & 0.737 & 0.008 & 0.000 & 0.000 & 0.187 & 0.000 & 0.042 & 0.003 \\
\hline \multirow[t]{2}{*}{$C 22: 5(n-3)$} & 0.039 & -0.028 & 0.941 & 0.966 & 0.018 & 0.295 & 0.530 & -0.333 & 0.093 & 0.226 & 0.423 \\
\hline & 0.842 & 0.886 & 0.000 & 0.000 & 0.926 & 0.127 & 0.004 & 0.083 & 0.637 & 0.326 & 0.056 \\
\hline \multirow[t]{2}{*}{$C 22: 6(n-3)$} & -0.042 & -0.403 & 0.145 & -0.618 & -0.535 & 0.126 & 0.024 & -0.462 & 0.638 & 0.154 & 0.599 \\
\hline & 0.887 & 0.154 & 0.620 & 0.018 & 0.049 & 0.668 & 0.936 & 0.096 & 0.014 & 0.599 & 0.004 \\
\hline
\end{tabular}

Upper values indicate Pearson's correlation coefficient; Lower values indicate level of significance at 5\% probability. Non-significant (P>0.05); Significant $(\mathrm{P}<0.05)$; Highly significant $(\mathrm{P}<0.01)$, WQPs; Water quality parameters, BOD; Biochemical Oxygen Demand, COD; Chemical Oxygen Demand, Phen; Phenols.

were missing in fish collected from the highly polluted habitat (Table-2). Loss of these beneficial fatty acids could not be compensated when majority of the diet comprises of fish meat. Cirrhinus mrigala, 
although widely cultured in the ponds but this fish species have least consumer preference in the vicinity of the River Chenab even from less polluted areas of the river due to the texture and aroma. Fish having high saturates accompanied with contaminants in the body requires more energy to perform daily activities especially during locomotion in struggle of food [7] as in our case Cirrhinus mrigala showed higher concentration of saturated fatty acids (Table-2; Fig. 2).

Fish is preferred as white meat only due to the presence of higher concentrations of polyunsaturated fatty acids. This study signifies that fish if grown in polluted waters would cause loss of beneficial fatty acids may be missing in the flesh of the fish reducing the quality of the fish meat as this study signified. High fat contents of Cirrhinus mrigala although help in the buoyancy as the density of the fat is lower than water $[7,14]$ but it deter the movement of the fish even in lower levels of the pollution. Perhaps this is among the major factors leading to the extinction of this fish species in polluted areas of the River Chenab. Fish from unpolluted areas clearly indicated higher levels of omega-3 polyunsaturated fatty acids and reasonable concentrations of the saturated fatty acids. Our previous study also verify that farmed fish is much better for consumption $[14,15]$ when fat is required for the energy and this study clearly indicated that River Chenab after receiving too much polluted water from variety of drains become unsuitable for fish growth to produce high quality meat. Previous study also reported the preference of wild fish when fish was consumed as source of white proteins [15]. Present study clearly revealed that before consuming wild fish for unsaturated fatty acids anybody must sure that fish is not approaching from the habitat of even lower intensity pollution because it may be deficit of essential fatty acids [7, 16, 17]. Heavy metals are present in the river water as a result of industrial and urban waste water discharge besides of natural sources. The major sources of $\mathrm{Mn}$ and $\mathrm{Zn}$ are the domestic wastes, municipal wastes followed by dumping [18]. $\mathrm{Pb}, \mathrm{Mn}$, $\mathrm{Hg}$ and $\mathrm{Cu}$ values in the water significantly higher than $\mathrm{Cd}$ may be explained by the fact that $\mathrm{Cd}$ sediment and is associated with the carbonate fraction and concentrates on the suspended matter having ability to mobilize from sediment to water. This argument was also supported by some studies [1921]. Concentrations of metals may be more in the river water as many studies revealed that in higher $\mathrm{pH}$ rate of sedimentation of metals is higher $[18,21$, 22] corroborating the findings of present study. Correlation coefficient matrix (significance at 5\% probability) for unsaturated fatty acids of omega series and some water quality parameters along with selected heavy metals is shown in Table-3.

It could be concluded from the present study that unhealthy habitats not only escort toxicant bioaccumulation in the fish tissues but also results in devastation of essential fatty acids. Prefer farmed fish or fish from entirely unpolluted environments when major concern is the need of unsaturated fatty acids of omega series. Reject fish even from mildly polluted areas with emphasis on conservative management of the water bodies. Peoples consuming fish for omega series of unsaturated fatty acids must ensure from where fish were harvested, as it may be deficient in these fatty acids.

\section{Acknowledgments}

This study is a part of $\mathrm{PhD}$ research work of a student Mr. Bilal Hussain. Authors wish to thanks to EPA of Pakistan and NIAB Faisalabad for providing research facilities and guidance.

\section{References}

1. Burr ML, Fehily AM, \& Gilbert JE (1989). Effect of changes in fat, fish and fiber intakes on death and myocardial reinfarction; diet and reinfarction trial (DART). Lancet 2: 757-761.

2. Polvi SM, \& Ackman RG (1992). Atlantic salmon (Salmo salar) muscle lipids and their response to alternative dietary fatty acid sources. J Agr Food Chem 40: 1001-1007.

3. Shahidi F, \& Boota J (1994). Seafood: chemistry, processing technology and quality, Chapman and Hall, London.

4. Piclet G (1987). Lepoisson aliment. Composition internet nutritional. Cah Nutr Diet 3: 317-336.

5. Klor H, Hauenschild A, Holbachi I, Kreshtchmer H, \& Stroh S (1997). Nutrition and cardiovascular disease. Eur J Med Res 2: 243-257.

6. Kiessling A, Pickova J, Johansson L, Asgard T, Storebakken T, \& Kiessling KH (2001). Changes in fatty acid composition in muscle and adipose tissue of farmed rainbow trout (Oncorhynchus mykiss) in relation to ration and age. Food Chem 73: 271-284.

7. Kandemir Ş, \& Polat N (2007). Seasonal variation of total lipid and total fatty acid in muscle and liver of rainbow trout (Oncorhynchus mykiss) reared in Derbent Dam Lakeb. TrJFAS 7: 27-31.

8. Boyd EC (1981). Water quality in warm water fish ponds. $2^{\text {nd }} \mathrm{Ed}$. Craftmaster Printers Inc Opelika Albama.

9. Folch J, Lees M, \& Stanely SGH (1957). A simple method for the isolation and purification of total lipids from animal tissues. J Biol Chem 226: 497-509.

10. Bell JG, Mcvicar AH, Park MT, \& Sargent RJ (1991). Effect of high dietary linolecic acid on 
fatty acid compositions of individual phospholipids from tissues of Atlantic salmon (Salmo salar): Association with a novel cardiac lesion. J Nutr 121: 1163-1172.

11.SAS (1995). Statistical Analysis Systems. S.A.S. Institute Inc. P.O. Box. 8000, Cary, North Carolina, USA.

12. Burger J, \& Gochfeld M (2005). Heavy metals in commercial fish in New Jersey. Environ Res 99: 403-12.

13. Koca S, Koca YB, Yildiz Ş, \& Gürcü B (2008). Genotoxic and Histopathological Effects of Water Pollution on Two Fish Species, Barbus capitopectoralis and Chondrostoma nasus in the Büyük Menderes River, Turk. Bio Tra Elem Res 122: 276-291.

14. Hussain B, Mahboob S, Hassan M, Nadeem S, \& Sultana $T$ (2011). Effect of maturation degree on fatty acid profile of different tissues in wild and farmed rohu (Labeo rohita). grasas y aceites 62: 206-212.

15.Hassan M, Chatha SAS, Tahira I, \& Hussain B (2010). Total lipids and fatty acid profile in the liver of wild and farmed catla catla fish. grasas y aceites 61: 52-57.

16. Anon (1992). Unsaturated fatty acids. Nutritional and physiological significance. British nutrition foundation report, The Report of the British Nutrition Foundation's Task Force. Chapman and Hall, London. pp. 156-157.

17. Nettleton JA (1991). n-3 Fatty acids: comparison of plant and seafood sources in human nutrition. J N Am Dvets Assoc 91: 331-337.

18. James WM (1991). Inorganic contaminations of surface water: Research and monitoring properties. Springer-Veralag. New York.

19. Goher MA (1998). Factors affecting the precipitation and dissolution of some chemical elements in River Nile at Damietta branch. M.Sc. Thesis fact of Sci Menofia Univ Egypt.

20. Tawfiq MEF (1998). Seasonal distribution of cadmium in Lake Nasser, Aswan reservoir and River Nile at Aswan." Monoufia J Agri Res 32: 391-414.

21.El-Bouraie MM, El-Barbary AA, Yehia MM, \& Motawea EA (2010). Heavy metal concentrations in surface river water and bed sediments at Nile Delta in Egypt. Suo 61: 1-12.

22. Nhapi I, Wali UG, Uwonkunda BK, Nsengimana H, Banadda N, \& Kimwaga BK (2011). Assessment of water pollution levels in the Nyabugogo Catchment, Rwanda. TOENVIEJ 4: 40-53. 